\title{
MAKNA REALISME MAGIS DALAM NOVEL JOURS DE COLÈRE DAN 'ENFANT MÉDUSE KARYA SYLVIE GERMAIN
}

\author{
Ferli Hasanah ${ }^{1)}$, Mega Subekti ${ }^{2)}$, dan Vincentia Tri Handayani ${ }^{3)}$ \\ Fakultas Ilmu Budaya Universitas Padjadjaran \\ email: 1)ferli.hasanah@unpad.ac.id, ${ }^{2}$ mega.subekti@unpad.ac.id \\ ${ }^{3)}$ v.tri@unpad.ac.id
}

\begin{abstract}
Abstrak
Dalam sastra, realisme magis dianggap sebagai alat yang ampuh untuk menunjukkan perlawanan terhadap kolonialisme dan neokolonialisme, terutama di negara berkembang yang sebagian besar masyarakatnya digambarkan masih menderita akibat efek destruktif kolonialisme. Penelitian bertujuan mendeskripsikan makna realisme magis dalam novel Jours de Colère dan l'Enfant Méduse karya Sylvie Germain. Dengan menggunakan pendekatan kualitatif dan metode deskriptif analitis, hasil penelitian ini menunjukkan bahwa hal-hal magis yang melekat pada tokoh-tokoh di kedua novel dapat diargumentasikan bermakna sebagai strategi untuk mengungkapkan berbagai kejadian ekstrem yang ada dalam novel seperti kekerasan seksual dan pembunuhan. Penggunaan realisme magis ini tidak berfungsi untuk membuat pembaca memahami, namun untuk merasakan peristiwa yang terjadi.
\end{abstract}

Kata Kunci: realisme magis, le mal, fantasi, trauma

\section{MEANINGS OF MAGICAL REALISM IN SYLVIE GERMAIN'S NOVELS JOURS DE COLÈRE AND 'ENFANT MÉDUSE}

\begin{abstract}
In literature, magicrealism is considered a powerful device to show resistance to colonialism and neocolonialism, especially in developing countries, where most of the people are depicted as still suffering from the destructive effects of colonialism. This study aims to describe meanings of magicrealism in Sylvie Germain's novels Jours de Colère and l'Enfant Méduse. The study used the qualitative approach and analytical descriptive method. The findings indicate that the magical things inherent in the characters in both novels can be argued as a strategy to express extreme events in the novels such as sexual violence and murder. Magic realism is not used to make the readers understand, but feel the occurring events.
\end{abstract}

Keywords: magicrealism, evil, fantasy, trauma

\section{PENDAHULUAN}

Istilah Realisme magis (réalisme magique) muncul pada tahun 1925 saat Franz Roh menerbitkan esainya menge- nai sebuah lukisan Jerman bergaya postexpressionistes. Meskipun pada tahun 1927 Massimo Bontempelli, pengarang Italia, telah menerapkan istilah terse- 
but pada karya sastra untuk menelusuri ciri fiksi modern, kelahiran realisme magis dalam karya sastra, khususnya novel, dipelopori oleh Gabriel Garcìa Márquez dengan terbitnya One Hundred Years of Solitude (1967). Dalam novelnya, bersama karya Isabel Allende The House of the Spirits (1982), Salman Rushdie Midnight's Children (1980), The Satanic Verses (1988), Toni Morrison Beloved (1987), Angela Carter's Nights at the Circus (1984), dan Ben Okri The Famished Road (1991), dapat ditemukan sebuah kesamaan, yaitu adanya unsur supernatural juga tidak masuk di akal yang diterima dan dianggap wajar sebagai bagian dari aspek kehidupan sehari-hari dalam cerita. Seperti yang Rushdie katakan, sebagaimana dikutip oleh Christopher Warnes, saat membicarakan tentang karya García Márquez, "impossible things happen constantly and quite plausibly, out in the open under the midday sun" (2009:3).

Dari segi terminologi, ada banyak rujukan definisi realisme magis, tidak hanya karena sejarahnya yang cukup panjang dan rumit, wacana ini ada dalam beberapa media seni, seperti seni lukis, maupun dalam film, jadi tidak hanya secara ekslusif dimiliki oleh karya sastra. Wendy B. Faris menjelaskan bahwa definisi realisme magis tertuang dalam lima karakterisik, yakni irreducible element (elemen yang tak tereduksi), phenomenal World (dunia yang fenomenal), unsettling doubt (keraguan yang tak terselesaikan), merging realms (alam yang bercampur), dan disruption of time, space, and identity (kekacauan waktu, ruang, dan identitas) (2004:7). Dalam Magical Realism: Theory, History, Community, Zamora dan Faris menjelaskan bahwa realisme magis dapat diang- gap sebagai perluasan dari gaya realis, namun menggugat logika kenyataan itu sendiri. Tubuh dan pikiran, hidup dan mati, nyata dan khayal, diri dan liyan, laki-laki dan perempuan, batasanbatasan ini yang dileburkan dan disatukan (1995:6).

Berkaitan dengan hal tersebut, Hart and Ouyang menjelaskan bahwa Magis dapat berarti semua hal yang menentang empirisme, termasuk kepercayaan dalam agama, tahayul, mitos, legenda, vodoo, atau yang Todorov sebut dengan istilah uncanny, marvellous, dan fantastique. (2005:14). Namun, genre sastra fantastique tidak sama dengan genre realisme magis. Todorov menjelaskan unsur-unsur fantastique dalam bukunya, Introduction à la littérature fantastique (1970):

Le fantastique occupe le temps de cette incertitude; dès qu'on choisit l'une ou l'autre réponse [l'événement est imaginaire ou l'événement est réel] Le fantastique, c'est l'hésitation éprouvée par un être qui ne connaît que les lois naturelles, face à un événement en apparence surnaturel. (Todorov, 1970:29)

Fantasi menempati waktu ketidakpastian; Saat kita memilih antara satu dengan yang lain (kejadian imajiner atau kejadian yang nyata) [...] fantasi, adalah keragu-raguan seseorang yang hanya mengetahui hukum alamiah, menghadapi kejadian yang tampak tidak alamiah. (Todorov, 1970:29)

Dengan demikian, dalam karya sastra bergenre fantastique pembaca selalu memiliki keragu-raguan, dan mempertanyakan kebenaran ceritanya, ragu- 
ragu antara yang nyata dan yang tidak nyata, yang alamiah dan tidak. Tetapi pada gaya realisme magis, pembaca diajak percaya bahwa hal-hal magis memang ada dan menjadi bagian dari kehidupan sehari-hari. Dalam hal ini, tidak ada lagi keragu-raguan atau pertanyaan, semua hal ajaib tampak wajar terjadi dalam karya realis magis. Ada perspektif yang melihat bahwa realisme magis datang dengan menawarkan dunia yang berlawanan, dunia realitas dan irealitas. Padahal jika ditelusuri baik melalui narasi maupun deskripsi dalam cerita, kedua unsur tersebut justru berjalan beriringan, tanpa ketegangan, tanpa ada pertanyaan terhadap satu dan yang lain (Chanady, 1985).

Sejak kemunculannya pada tahun 60-an, realisme magis telah menjadi salah satu teknik penceritaan yang cukup berkembang dalam sastra postkolonial karena dianggap sebagai alat yang ampuh untuk menunjukkan perlawanan terhadap kolonialisme dan neokolonialisme, terutama di negara berkembang yang sebagian besar masyarakatnya digambarkan masih menderita akibat efek destruktif kolonialisme. Selain menekankan identitas hybrid dan multikultural masyarakatnya untuk menunjukkan perlawanan terhadap semua jenis struktur politik, sosial, dan budaya unilateral, teks realis magis biasanya bersifat subversif dan reformis (Faris dan Zamora, 1995:6).

Sementara itu, Eugene Arva menyatakan bahwateknik pemaparan cerita dengan realisme magis erat kaitannya dengan masalah trauma. Realisme magis mampu mengungkapkan kejadiankejadian traumatis yang tidak dapat dilakukan oleh cerita realis biasa (2008: 3). Arva mengajukan istilah traumatic imagination yang berarti kesadaran pengarang dan pembaca untuk berdialog melalui narasi realisme magis. Jika dikaitkan dengan kemunculan pertama genre ini di berbagai negara, dapat ditelusuri bahwa realisme magis selalu terkait dengan trauma kolektif seperti penjajahan, perbudakan, genosida, dan kejahatan kemanusiaan lainnya.

Mengenai kejahatan, Kristeva mengemukakan teori abjek, yaitu segala sesuatu yang mengganggu identitas, sistem, tatanan. Apa yang tidak menghormati batasan, posisi, aturan-aturan (1982: 4). Abjek juga berarti penyimpangan (perversion) karena tidak pernah tunduk pada larangan atau hukum. Oleh karena itu, kriminalitas juga termasuk pada abjek karena menunjukkan kerapuhan hukum. Abjek juga terkait erat dengan tubuh perempuan karena dianggap tidak stabil serta banyak mengalami perubahan dan perkembangan jika dibandingkan dengan tubuh laki-laki. Perubahan tubuh paling yang signifikan dialami perempuan adalah ketika menjadi seorang ibu. Tubuh ibu terkait erat dengan berbagai cairan yang dianggap menjijikan, seperti urin, kotoran, dan darah. Kristeva menekankan bahwa menjadi ibu juga bernilai ambigu, yaitu désirable et terrifiant, nourricier et meurtrier, fascinant et abject (diinginkan dan menakutkan, memelihara dan membunuh, mempesona dan abjek (1982: 66).

Gaya penulisan realisme magis telah menawarkan sebuah kebaruan sehingga karakteristik yang sama selanjutnya dapat ditelusuri dalam karya sastra di berbagai belahan dunia, termasuk pada karya sastra frankofon. Setidaknya ada tiga pengarang perempuan frankofon yang dianggap memiliki gaya realisme 
magis dalam karya mereka, yaitu Maryse Condé, Marie NDiaye dan Sylvie Germain. Adapun dalam tulisan ini, kami akan membahas realisme magis pada dua novel Germain, yaitu Jours de Colère dan l'Enfant Méduse.

Sylvie Germain, penulis perempuan yang telah menulis puluhan karya berupa novel, esai sastra, dan esai filosofis ini, telah mendapatkan beberapa penghargaan bergengsi dalam bidang sastra di Perancis, beberapa di antaranya adalah Prix Fémina untuk novel Jours de Colère (1989), dan Prix Goncourt des Lycéens untuk novel Magnus (2005). Meskipun karya Germain tidak secara sadar menggugat aliran/genre tertentu, tulisannya dianggap melampaui batasan-batasan novel tradisional. Novel-novel Germain sendiri banyak mengacu pada tema kejahatan (le mal). Baginya, keburukan ada di mana-mana dan ada di setiap orang (Goulet, 2006: 25).

Selain itu, karakteristik yang melekat dalam gaya penulisannya adalah adanya berbagai hal magis dalam latar ceritanya yang realis. Oleh karena itu, kritikus sastra banyak mengaitkannya dengan wacana realisme magis seperti dalam buku Décoloniser L'imaginaire yang ditulis oleh Katherine Roussos (2007), meskipun tidak dikhususkan pada karya Germain saja, serta dalam tulisan Annick Jauer (2016) berjudul Hybridité et altérité dans Magnus de Sylvie Germain yang memfokuskan pembahasan pada teknik naratif realisme magis novel Magnus. Selain itu, pembahasan karya Germain yang dikaitkan dengan trauma telah dilakukan Horáčková dalam disertasinya La Pleurante des rues de Prague, Immensités, dan Éclats de sel atau yang lebih dikenal dengan Trilogi Praha. Horáčková meng- khususkan analisisnya padatrauma akibat Perang Dunia Kedua, opresi pada era komunis, dan Revolusi Beludru (Velvet Revolution) yang menjadi latar cerita (Horáčková, 2014: 246).

Melalui penelusuran tersebut diketahui bahwa tiga penelitian di atas memiliki persinggungan dengan penelitian ini, khususnya pada penggunaan teori realisme magis dalam karya-karya Germain. Meskipun demikian, pembahasan realisme magispada novel Jours de Colère dan l'Enfant Méduse belum banyak dilakukan. Oleh karena itu, fokus kajian tulisan ini, yaitu: (1) bagaimana realisme magis ditampilkan dalam novel Jours de Colère dan l'Enfant Méduse; (2) Makna realisme magis pada kedua novel.

\section{METODE}

Penelitian ini adalah penelitian kualitatif dengan menggunakan metode deskriptif analitik yang melakukan pembahasan dengan cara mendeskripsikan fakta-fakta kemudian disusul dengan analisis (Ratna, 2011: 53). Dua sumber data dalam penelitian ini yaitu sumber literer sebagai data utama dari dua novel Sylvie Germain yaitu Jours de Colère (1989) dan l'Enfant Méduse (1993) serta sumber nonliterer berupa teori-teori sebagai penunjang penelitian. Teori Faris (1995) dan Arva (2008) digunakan sebagai teori utama yang untuk melihat berbagai fenomena realisme magis yang ada pada dua novel tersebut.

Dengan menggunakan berbagai teori yang telah dikemukakan, teks dua novel Germain dianalisis untuk mendapat data mengenai realisme magis. Teknik pengumpulan data dilakukan dengan metode pustaka. Teknik pembacaan dan pencatatan dilakukan un- 
tuk memperoleh data dalam teks novel. Data yang didapatkan selanjutnya dianalisis dan diinterpretasikan sehingga makna realisme magis dalam kedua novel dapat diungkapkan. Interpretasi data dilakukan dengan mencantumkan kutipan dari beberapa bagian teks novel yang relevan dengan pembahasan. Terakhir, hasil analisis tersebut disimpulkan untuk memperoleh pemahaman yang menyeluruh.

\section{HASIL DAN PEMBAHASAN}

Dengan memfokuskan penelitian pada fenomena realisme magis dalam novel Jours de Colère dan l'Enfant Méduse (selanjutnya disingkat menjadi JC dan EM), maka penelitian berhasil menemukan dua hal, yaitu (1) Novel JC dan EM memiliki strategi naratif realisme magis (2) Fenomena realisme magis menjadi strategi para tokoh dalam mengungkapkan trauma mendalam baik yang disaksikan maupun yang dialami.

\section{Hasil}

Pada bagian ini, dipaparkan persamaan dan perbedaan Novel JC dan EM dari segi struktur cerita, realisme magis, serta trauma para tokoh sebagai hasil dari observasi kedua novel.

\section{a. Struktur Cerita novel JC dan EM}

Dari segi alur, cerita kedua novel ini tidak bersifat kronologis. Tetapi, hal tersebut tidak lantas menjadikan ceritanya tidak logis. Terkadang pembaca dihadapkan dengan sebuah peristiwa yang tidak ada penjelasan alasan dan prosesnya. Namun di bab selanjutnya, pembaca akan menemukan penjelasan narator mengenai peristiwa tersebut. Oleh karena itu, ada semacam teka-teki (l'énigme) di alur kedua novel ini. Pada aspek latar, kedua novel ini berlatarkan pedesaan, tokoh-tokohnya mempunyai hubungan dan interaksi yang erat dengan alam sekitarnya, seperti hutan, sungai, serta binatang. Selanjutnya dari segi sudut pandang, kedua novel ini menggunakan sudut pandang orang ketiga (dia-an) yang tidak terlibat sebagai tokoh dalam cerita. Terkait tema, ada beberapa tema besar yang sama di dalam JC dan EM yaitu tema mengenai keluarga, kejahatan, adanya obsesi terhadap orang yang telah meninggal, dan perilaku seksual menyimpang. Tematema ini dapat digambarkan sebagai berikut:

\begin{tabular}{|c|c|c|c|}
\hline No. & Tema & Novel & $\begin{array}{c}\text { Tokoh } \\
\end{array}$ \\
\hline \multirow[t]{2}{*}{1.} & Keluarga & $\mathrm{JC}$ & Keluarga Mauperthuis, Verselay dan Corvol \\
\hline & & EM & Keluarga Daubigné \\
\hline \multirow[t]{2}{*}{2.} & Kejahatan & $\mathrm{JC}$ & Pemerasan, Pembunuhan, balas dendam \\
\hline & & EM & $\begin{array}{l}\text { Pembunuhan, pemerkosaan, balas } \\
\text { dendam }\end{array}$ \\
\hline \multirow[t]{2}{*}{3.} & Obsesi terhadap orang yang meninggal & $\mathrm{JC}$ & $\begin{array}{l}\text { Ambroise Mauperthuis terhadap } \\
\text { Catherine Corvol }\end{array}$ \\
\hline & & EM & Aloïse Daubigné -> Victor Morrogues \\
\hline \multirow[t]{2}{*}{4.} & Perilaku seksual menyimpang & $\mathrm{JC}$ & $\begin{array}{l}\text { - Ambroise Mauperthuis terhadap } \\
\text { mayat Catherine } \\
\text { - Ambroise Mauperthuis (kakek) pada } \\
\text { tokoh Camille sebagai cucunya }\end{array}$ \\
\hline & & EM & Ferdinand (kakak) terhadap Lucie (adik) \\
\hline
\end{tabular}


Dari intisari struktur cerita yang telah dipaparkan, dapat diargumentasikan bahwa pada dua novel yang dianalisis ini terdapat persamaan dalam segi alur, latar, sudut pandang, dan tema. Pada aspek tema, dapat diketahui bahwa tema-tema kejahatan lebih banyak mendominasi cerita kedua novel, sejalan dengan yang Goulet (2006) ungkapkan bahwa keburukan dalam novel Germain ada di mana-mana.

\section{b. Realisme magis}

Hal-hal magis yang ada di novel terkait dengan dua aspek, yaitu pada tokoh dan peristiwa. Dalam novel JC realisme magis pada tokoh ada pada penggambaran tokoh Reine Verselay, sedangkan peristiwa yang mengandung unsur magis adalah peristiwa terbunuhnya Catherine dan kematian Reine Verselay. Sementara itu, pada novel EM tokoh magis ada pada Lucie Daubigné yang digambarkan sebagai anak medusa dan peristiwa magis yang terjadi ada pada penggambaran peristiwa kematian Ferdinand Morrogue.

\section{c. Trauma tokoh}

Mengacu pada Arva (2008) yang mengatakan bahwa realisme magis selalu berkaitan dengan kejadian traumatis, berikut adalah hasil temuan peristiwa traumatis pada tokoh Germain:

\begin{tabular}{crll}
\hline No. & Trauma & \multicolumn{1}{c}{ Tokoh JC } & Tokoh EM \\
\hline 1. & Pembunuhan & $\begin{array}{l}\text { Ambroise } \\
\text { Mauperthuis }\end{array}$ & - \\
2. & $\begin{array}{l}\text { Perilaku } \\
\text { seksual } \\
\text { menyimpang }\end{array}$ & $\begin{array}{l}\text { Camille } \\
\text { Corvol }\end{array}$ & $\begin{array}{l}\text { Lucie } \\
\text { Daubigné }\end{array}$ \\
3. & Kematian & Simon & $\begin{array}{l}\text { Aloise } \\
\text { daubigné }\end{array}$ \\
\hline
\end{tabular}

Tabel di atas menggambarkan penyebab trauma yang dialami oleh para tokoh dalam dua novel Germain, yaitu pembunuhan, perilaku seksual menyimpang dan kematian orang yang dicintai. Penyebab pertama, yaitu pembunuhan, dalam novel JC adalah peristiwa pembunuhan Catherine Corvol yang menimbulkan trauma pada tokoh utama, Ambroise Mauperthuis. Kedua, dalam novel EM, meskipun terdapat peristiwa pembunuhan yang dilakukan oleh tokoh Ferdinand terhadap dua gadis kecil, Irène dan Anne-Lise, yang menghantui pelakunya, tidak ada penggambaran trauma dari korban kejahatan, dalam hal ini, misalnya, dari keluarga dua gadis yang ditinggalkan. Selanjutnya, perilaku seksual yang menyimpang yang menimbulkan trauma dialami oleh keluarga terdekat pelaku, dalam JC yaitu cucu dan dalam novel EM, adik pelaku kejahatan. Hubungan seksual ini bukanlah inses, karena tidak ada hubungan saling mencintai, yang ada adalah pemaksaan kehendak dari tokoh laki-laki yang kuat, terhadap tokoh perempuan yang lemah. Tidak seperti dalam novel EM yang terjadi kekerasan seksual berupa pemerkosaan, dalam novel JC, hubungan kakek-cucu tidak sampai pada hubungan seksual. Ketiga, kematian orang yang sangat dicintai juga menimbulkan rasa kehilangan yang sangat mendalam. Dalam novel JC, kematian Reine Verselay adalah penyebab kesedihan Simon, sedangkan pada EM, tokoh Aloise berduka karena kehilangan suaminya, Victor Morrogues, yang meninggal akibat perang.

Dari pemaparan mengenai perbandingan novel JC dan EM, dapat diketahui bahwa meskipun ada beberapa 
perbedaan, terdapat banyak persamaan yang ada pada kedua novel, persamaan ini ada pada aspek struktur cerita, narasi realisme magis, serta trauma para tokoh. Selanjutnya pembahasan akan difokuskan pada strategi naratif dan traumatisme para tokoh.

\section{Pembahasan}

Pembahasan dibagi menjadi dua subbab: (1) strategi naratif realisme magis dalam novel JC dan EM. Strategi naratif dianalisis untuk melihat bagaimana realisme magis menjadi efektif untuk mengungkapkan trauma; (2) Traumatisme dalam kedua novel. Pada subbab kedua pembahasan memaparkan penyebab trauma yang dialami para tokoh dan makna realisme magis pada kedua novel.

\section{Strategi Naratif Realisme Magis Dalam Novel JC dan EM}

Dawn Miranda Sherratt-Bado menjelaskan pada teks-teks yang diterbitkan selama momen pascakonflik, trauma diejawantahkan dalam bentuk elemen narasi realis magis seperti peristiwa dan tokoh surealis, khayal, dan fantastik (2018:2). Sejalan dengan pandangan Sheratt-Bado itu, elemen-elemen realisme magis pada dua novel yang dianalisis adalah peristiwa dan para tokoh.

Narator JC adalah narator orang ketiga yang tidak terlibat sebagai tokoh dalam cerita yang Genette sebut sebagai narator extradiégetique (1972: 239). Meskipun narator bersifat maha tau (omniscient), ia tidak lantas menceritakan berbagai peristiwa secara berurutan dan terperinci. Peristiwa-peristiwa disajikan terpenggal-penggal di beberapa bab. Dengan gaya seperti ini, pembaca harus mengikuti jalan cerita yang tidak kronologis dan menikmati apa yang tengah narator ceritakan.

Dalam Bab pertama novel JC narator mendeskripsikan kondisi desa yang menjadi latar cerita. Desa terpencil yang terletak di gunung ini dikelilingi hutan. Selain latar cerita, di awal narator menjelaskan dua keluarga yang akan menjadi fokus utama cerita, yaitu keluarga Mauperthuis dan keluarga Verselay. Tokoh utama dalam cerita ini adalah tokoh Ambroise Mauperthuis yang memiliki porsi penceritaan paling banyak.

Tokoh Ambroise Mauperthuis adalah tokoh yang dipenuhi oleh rahasia. Misteri-misteri yang tersembunyi ini yaitu misteri rahasia pembunuhan Catherine Corvol, misteri kekayaan yang mendadak Ambroise dapatkan, obsesinya untuk menghidupkan lagi sosok Catherine, rasa cinta Ambroise untuk cucunya sendiri, Camille, serta rahasia bahwa ia adalah pembunuh tokoh Simon dan Camille. Dengan banyaknya rahasia ini, cerita JC menjadi penuh dengan kejutan tidak terduga. Sedikit-demi sedikit rahasia-rahasia itu diungkap oleh narator dengan menyebarkannya di bab-bab yang terpisah. Hal yang menarik adalah pengetahuan mengenai berbagai rahasia itu hanya dimiliki oleh narator dan pembaca saja, artinya tokoh-tokoh lain dalam cerita, dikisahkan tidak mengetahui rahasia yang ada pada tokoh utama.

Terkait hal tersebut, Deleuze dan Guattari menyatakan bahwa novel (roman) pada prinsipnya terkait dengan un secret (rahasia) (Deleuze \& Guattari, 1980: 237). Rahasia dalam novel dapat dibuka sedikit demi sedikit dengan cara membacanya, tetapi tidak berarti semua hal menjadi jelas, karena masih tersisa 
rahasia-rahasia lain yang tetap tersimpan di dalamnya. Pada novel realisme magis, Lutas mengungkapkan tujuan dari teknik ini adalah, antara lain, untuk menunjukkan betapa sulitnya tokoh untuk memahami apa yang terjadi dan teknik naratif ini digunakan seperti dalam puzzle, yaitu mendorong pembaca untuk mengurai benang-benang narasi dan merekonstruksi realitas (2017: 72). Seperti dalam JC, tokoh utama dipenuhi rahasia dan narator mengungkapkan peristiwa penting yang dialami tokoh itu secara bertahap.

Kehidupan penuh rahasia tokoh Ambroise dalam JC dimulai saat narator menceritakan peristiwa pembunuhan tokoh Catherine Corvol yang dilakukan oleh suaminya, Tuan Corvol. Peristiwa pembunuhan ini digambarkan secara magis dan terkesan mistis "Quelque chose comme un silence; un silence très étrange [...] un silence si aigu, si dense, implacable [...] Il s'immisçait sous la peau d'Ambroise Mauperthuis comme une sueur glacée" (Sesuatu seperti keheningan; keheningan yang sangat aneh [...] keheningan yang begitu tajam, padat, tiada henti. [...] Keheningan itu mengganggu kulit Ambroise Mauperthuis seperti keringat dingin) (Germain, 1989: 39, penekanan ditambahkan oleh peneliti).

Dari kutipan tersebut, narator mengungkapkan bahwa Ambroise secara tiba-tiba terbangun oleh sesuatu yang berasal dari luar, sesuatu yang dirasakan aneh, yaitu silence (keheningan). Kata silence yang muncul sembilan kali dalam satu halaman, yaitu halaman 39 , adalah sesuatu yang jelas ingin ditekankan oleh Germain. Kata aigu, dense, dan commeune sueur glacée mengindikasikan bahwa seolah keheningan itu sesuatu yang berbentuk dan nyata, dapat didengar dan dirasakan. Setelah itu, narator mengungkapkan peristiwa pembunuhan Catherine Corvol yang disaksikan Ambroise. Dengan demikian, Ambroise tidak mungkin menyaksikan peristiwa pembunuhan itu jika tidak ada keheningan yang menariknya untuk pergi ke hutan.

Hal magis lain dalam JC ada pada tokoh perempuan bernama Reine Verselay yang memiliki tubuh sangat gemuk hingga diberi julukan Reinette $L a$ Grasse (Reinette si Lemak). Merujuk Kristeva (1982) Bentuk tubuh Reinette yang gemuk, termasuk ke dalam kategori abjek. Tubuh yang gemuk dan berlemak membawa stereotypes tersendiri, seperti orang yang banyak makan, lamban, dan pemalas. Penegasan bahwa bentuk tubuh yang gemuk adalah tidak diinginkan dalam novel ini adalah dari olok-olokan masyarakat terhadapnya yang memanggilnya dengan kata $L a$ Grasse. Stereotype yang terbukti benar pada tokoh ini adalah ia memang lamban dan banyak makan.

Dilihat dari segi karakter, narator tidak menggambarkan tokoh Reinette dengan sifat-sifat tertentu, kecuali pada rasa lapar. Reinette digambarkan sebagai perempuan yang tidak mempedulikan hal-hal lain yang ada di sekelilingnya. Sekilas narator juga menekankan Reine mengidap hyperphagia/polifagia, yakni kelainan metabolisme tubuh berupa tingginya ritme rasa lapar yang harus dipuaskan dengan mengonsumsi banyak makanan. "... jamais elle ne parvenait à assouvir sa faim. la faim hantait son corps.» (ia tidak pernah bisa memuaskan rasa laparnya. Rasa lapar itu menghantui tubuhnya) (1989: 22). Narator juga mengibaratkan Reine sebagai un petit animal vorace (binatang kecil yang 
rakus) (1989 : 22) karena rasa laparnya tersebut. Ungkapan itu menegaskan keanehan pada diri Reinette karena hal yang dipedulikan Reinette hanyalah rasa lapar.

Meskipun demikian, narator juga menggambarkan Reine seperti dewi kesuburan, Reinette diceritakan memiliki banyak anak dengan jumlah yang sama sesuai nama depan Reinette yang didaftarkan ibunya di catatan sipil (1989: 20), yaitu sembilan orang. Keistimewaannya adalah ia melahirkan sembilan anak dalam waktu sembilan tahun pada bulan dan hari yang sama. Di setiap bulan Agustus, keluarga Reinette mendapatkan seorang bayi laki-laki baru. Peristiwa kelahiran bayi pada waktu yang sama adalah salah satu aspek realisme magis yang Faris katakan sebagai suatu kejadian ajaib yang tidak dapat dijelaskan secara ilmiah (1995). Proses menjadi ibu sendiri dianggap luar biasa karena seorang perempuan yang dianggap lemah dapat berubah menjadi manusia super yang dapat mengandung dan melahirkan (memberi kehidupan) manusia lain. Sementara dalam novel JC, Germain melipatgandakan kekuatan ini melalui tokoh Reinette yang mampu melahirkan sembilan anak dalam waktu sembilan tahun.

Dengan demikian, tokoh Reinesebagai ibu yang bertubuh monster tentu tidak dapat disejajarkan dengan monster ibu yang lain, contohnya, Ibu Grendel dalam kisah Beowulf, yang meski menyayangi anaknya, senang membunuh manusia. Reinette digambarkan tidak pernah menyakiti siapapun. Kekuatan Reinette dalam melahirkan sembilan orang anak dapat dimaknai sebagai penolakan Germain terhadap the act of birth yang dianggap grotesque. Seba- liknya, narator menggambarkan the act of birth Reinette sebagai pemberi kehidupan. Anak-anak Reinette adalah tubuh-tubuh yang mengelilingi ibunya, adalah tubuh yang mendapatkan kehidupan, menemukan kedamaian, tubuh yang tumbuh menjadi laki-laki, dan mereka telah menolong sang ibu mengatasi rasa laparnya (JC: 214). Oleh karena itu, dapat dikatakan bahwa Germain melihat proses melahirkan adalah suatu keistimewaan dan bukti kekuatan perempuan. Dari penggambaran tokoh Reine, Germain menghadirkan kontradiksi sejalan dengan apa yang Kristeva (1982) ungkapkan bahwa ibu adalah "fascinant et abject" (memesona dan abjek).

Sementara itu, pada novel EM, narasi dibagi berdasarkan lima judul besar, yaitu Enfance, Lumière, Vigiles, Appels, dan Patience. Setiap judul tersebut memuat tiga sub bab yang dimulai dengan deskripsi dalam bentuk kala présent, mengenai suasana tempat dan waktu sebelum aksi maupun peristiwa terjadi. Setiap judul bab dan suasana yang dibangun dalam paragraf bergaris miring selalu terkait dengan peristiwa yang akan terjadi di bab tersebut. Sebagai contoh, bab pertama Enfance menceritakan masa kecil tokoh Lucie yang bahagia sebelum mengalami peristiwa pemerkosaan.

Germain menunjukkan tanda akan adanya perubahan cerita, dalam penggambaran suasana di bab pertama yang menceritakan gerhana matahari. Gerhana diumpamakan seperti loup céleste (serigala langit) (Germain, 1991: 16) yang melahap cahaya. Loup (serigala) adalah sebuah kata yang berkonotasi predator. Peristiwa gerhana matahari dalam beberapa mitos menjadi tanda 
kehancuran dan kematian. Gerhana dianggap sebagai kematian matahari karena dimakan sesaat oleh binatang yang berbeda-beda, tergantung dari wilayah asal mitos tersebut. Binatang ini dapat berupa kucing liar, ular, atau seperti dalam novel l'Enfant Méduse, serigala. Jika dikaitkan dengan peristiwa yang akan terjadi di novel ini, gerhana adalah pertanda bahwa sesuatu yang buruk akan terjadi, yaitu peristiwa pemerkosaan.

Selain itu, masih pada bab Enfance, diceritakan bahwa sahabat Lucie yang bernama Lou-Fé, bercita-cita menjadi astronot dan mengagumi bintang-bintang (Le petit prince des étoiles) (pangeran kecil bintang-bintang) (Germain, 1991:21) sedangkan Lucie menyukai dongeng-dongeng. Lucie bersikeras bahwa ia dan Lou-Fé harus memakai scarf merah yang sama karena il est son jumeau (Lou-Fé adalah saudara kembarnya) (Germain, 1991:28). Jika dihubungkan dengan kisah perbintangan dan mitologi Yunani, keduanya mengacu pada Gemini (si kembar).

Warna merah juga sering diasosiasikan dengan rasi bintang Gemini. Dalam mitologi, rasi bintang Gemini diasosiasikan pada saudara kembar Castor dan Pollux atau sering juga disebut Polydeuces/ Dioscuri, saudara kembar yang dikandung oleh Leda. Pollux berayahkan Zeus dan oleh karena itu ia abadi (immortal), sementara itu Castor berayahkan Tyndareus, suami Leda dari bangsa manusia yang membuat Castor juga fana (mortal).

Germain menggunakan Dioscuri (les jumeaux), untuk menerangkan hubungan antara Lucie dan Lou-Fé. Lou-Fé dapat disejajarkan pada Pollux berdasarkan obsesinya pada bintang- bintang. Lou-Fé berkata Quand je serai grand...je serai astronome (saat aku besar nanti... aku akan menjadi ahli astronomi) (Germain, 1991: 20). Kesejajaran LouFé dengan dunia langit, menyiratkan keabadian Pollux. Sementara itu, Lucie dapat dihubungkan pada Castor, yang terobsesi pada alam, binatang, dan rawa-rawa, sehingga ia lebih bersifat terrestrial (bumi). Karena bersifat abadi, dalam cerita EM, Lou-Fé terhindar dari segala bahaya dan terjaga dalam kondisi baik hingga ia tumbuh dewasa. Sementara kefanaan Castor yang terdapat pada tokoh Lucie, membuatnya mendapatkan musibah, yaitu kekerasan seksual hingga Lucie berubah ke arah keburukan (le mal) baik dari segi fisik maupun karakter.

Jika dikaitkan dengan kisah Orphée-Eurydice, kehidupan tokoh Lucie juga dapat terhubung seperti kehidupan Orphée yang melakukan perjalanan ke neraka karena kehilangan Eurydice. Lucie yang kehilangan sahabatnya, LouFé karena Lou Fé sera en pension (mulai sekarang Lou-Fé akan tinggal di asrama) (Germain, 1991:71), seolah digambarkan turun ke underworld. Pernyataan ini didasari oleh kecenderungan Lucie yang mendekatkan diri pada alam. Selain, turun ke rawa-rawa, ia merasa dekat dengan mahluk-mahluk 'neraka' yang disimbolkan oleh kodok, kadal, dan ular hingga kamarnya berubah seperti laboratorium kecil karena memelihara berbagai binatang tersebut. Dunia Lucie terisolasi dari manusia sekitarnya. Ia menolak berhubungan dengan keluarga maupun teman-teman sebayanya.

Kontradiksi dua tokoh itu merupakan cara narator menegaskan perbedaan tokoh Lucie dengan anak yang 
lain. Lucie yang menjadi korban pemerkosaan kakaknya sendiri, mengalami trauma yang begitu dalam hingga masa kanak-kanaknya terenggut oleh peristiwa ini. Pemerkosaan bagi Lucie yang berumur delapan tahun adalah kejadian ekstrem yang tidak dapat ia pahami. Oleh karena itu, narator membuat alusi pada mitos dan menyajikan metafora dalam narasinya. Merujuk Schönfelder teks sastra yang menggunakan imajinasi dan metafora memungkinkan pembaca untuk memiliki kekuatan emosial mengidentifikasi diri mereka, menggugah simpati, sekaligus memiliki refleksi kritis pada masalah itu (2013: 29). Mengenai trauma, Balaev (2008) juga mengungkapkan bahwa pengalaman traumatis menjadi tidak dapat direpresentasikan secara jelas karena ketidakmampuan otak untuk mencerna kejadian itu. Oleh karena itu, pada narasi yang mengungkapkan trauma akan ditemukan repetisi flashback sebagai teknik penceritaan karena pikiran dipaksa untuk mengingat peristiwa yang ingin dilupakan. Dengan demikian, dalam novel JC dan EM yang menggunakan gaya realisme magis, terdapat alur cerita tidak kronologis, pengulangan flashback, dan penggunaan berbagai metafora yang merupakan strategi yang efektif untuk menarasikan trauma para tokohnya.

\section{Traumatisme Para tokoh dalam Novel JC dan EM}

Dalam novel JC, Ambroise Mauperthuis mengalami trauma akibat kehilangan seseorang yang ia cintai, yaitu Catherine Corvol. Pembunuhan tokoh Catherine Corvol adalah peristiwa yang menjadi inti utama cerita karena kelanjutan JC bergulir berdasarkan peristi- wa ini. Tanpa diduga, Ambroise yang setuju untuk mengurus jasad Catherine merasakan kekaguman atas kecantikan Catherine sehingga ia merasa geram karena kecantikan itu mati sia-sia. Ambroise juga berhasil memeras Tuan Corvol dengan meminta seluruh tanahnya sebagai bayaran untuk menjaga rahasia peristiwa pembunuhan itu. Melalui paparan narator diungkapkan apa yang dilakukan tokoh Ambroise Mauperthuis terhadap jasad Catherine Corvol. Sebelum menguburkannya, ia mengagumi tubuh Catherine dengan mengelus tubuh, mencium bibir, bahkan menjilati darahnya (Germain, 1989: 44).

Dari peristiwa tersebut, aspek abject (kristeva: 1980) disajikan pada pembaca melalui jasad Catherine yang berada di luar tatanan bersih, layak, dan terutama, hidup. Un Cadavre (mayat) yang selayaknya diabjeksi karena merupakan the ultimate abject, menjadi objek yang dikagumi oleh tokoh Ambroise. Dalam satuan peristiwa ini Germain menyajikan konfrontasi antara yang hidup (Ambroise Mauperthuis) dan yang mati (Catherine Corvol).

Setelah melihat jasad Catherine, tokoh Ambroise selalu dihantui oleh keindahan tubuh perempuan itu dan keintiman yang ia lakukan terhadap jasadnya. Dengan perkataan lain, Ambroise mengalami trauma akan kematian Catherine, perempuan yang begitu dikaguminya. Trauma ini kemudian berubah menjadi hasrat dan obsesi untuk menghidupkan kembali sosok perempuan itu. Dengan menjodohkan salah satu anaknya dengan Claude Corvol, putri Catherine Corvol, ia berhasil melakukannya. Narator menegaskan hasrat terdalam Ambroise yang tidak diketahui tokoh manapun ini, dengan 
pengulangan dua kali kata l'espoir (harapan), verba voir (melihat) dan revoir (melihat lagi) sejumlah empat kali pada satu paragraf di halaman 62 novel JC, yang menggambarkan keinginannya untuk melihat sosok Catherine lagi.

Sosok Catherine seolah hidup kembali pada cucunya, Camille. Narator menggambarkan Camille sebagai seorang gadis yang memiliki matahari sebagai mantel, bulan di bawah kakinya, dan di kepalanya sebuah mahkota dari dua belas bintang (Germain, 1989: 169). Gambaran hiperbola tersebut menegaskan kecantikan tokoh Camille yang dikagumi Ambroise. Keinginan Ambroise ini disebutkan sebagai kegilaan yang didasari l'amour et la colère (cinta dan kemarahan), dan le désir et la mort (hasrat dan kematian) (Germain, 1989: 15). Dengan demikian, trauma tokoh Ambroise akan kematian Catherine bertransformasi menjadi sesuatu yang lain, yaitu obsesi dan kegilaan. Bahkan kegilaan ini berlanjut dengan sikap posesif Ambroise terhadap Camille. Menurut Ambroise, karena dia adalah orang yang telah menghidupkan/ menciptakan Camille, maka ia berhak untuk memiliki Camille di sisinya (Germain, 1989 : 173). Oleh karena itu, saat tokoh Simon mendekati Camille, Ambroise merasa ketakutan akan kehilangan cucu yang dicintainya itu sehingga ia mengurung Camille di sebuah kamar dan mengusir Simon dari desa.

Duka yang mendalam juga dialami oleh tokoh Simon yang kehilangan ibunya, Reine Verselay. Reine Verselay diceritakan meninggal karena tidak mampu menanggung kesedihan atas kehilangan Simon yang diusir dari desa. Kabar kematian Reine yang sampai pada Simon digambarkan secara magis,
Un matin, il sentit un souffle lui parcourir les mains, le visage, un souffle très léger, qui n'était ni de vent, ni de brise [...] celle de sa mère. [...] il se sentit soudain, à son réveil, caressé par la main si menue de sa mère, et il lui sembla voir son sourire [...] et il lui sembla percevoir un murmure tout contre son oreille: " je suis là, mon petit, je t'ai enfin retrouvé, je t'ai rejoint..." la voix de sa mère chuchotait en lui, tout contre son cour... (Germain, 1989 : 219)

Suatu pagi, ia (Simon) merasakan hembusan di tangannya, wajahnya, hembusan yang sangat halus, bukanlah angin atau udara [...] ini adalah hembusan ibunya. [...] dia tiba-tiba merasakan, saat ia terbangun, belaian tangan mungil ibunya, dan ia merasa melihat senyumannya [...] dan ia merasakan bisikan pada telinganya : " aku di sini, sayangku, aku akhirnya menemukanmu, aku bersamamu... " suara ibunya berbisik dalam dirinya, hingga ke dalam hatinya... (Germain, 1989 : 219)

Kutipan data tersebut menggambarkan peristiwa magis yang dialami tokoh Simon saat ibunya telah meninggal. Arwah ibunya seolah mendatangi Simon dan berbicara kepadanya. Ibu dan anak laki-lakinya ini digambarkan sangat menyayangi satu sama lain. Kepergian Simon telah membuat Reine terpuruk hingga mengganggu kesehatannya dan Reine pun meninggal. Kematian orang yang dicintai adalah salah satu penyebab trauma yang akan meninggalkan luka mendalam. Trauma ini tentu tidak akan ada jika hubungan antara orang yang meninggalkan dan ditinggalkan tidak terjalin kuat. Kehilangan orang yang dicintai akan menyisakan 
kenangan yang terus ada di alam bawah sadar orang yang ditinggalkan (Harvey, 2002).

Pada novel EM, trauma yang dialami tokoh utama Lucie Daubigné diakibatkan olehpemerkosaan yang dilakukan oleh kakak tirinya. Sejalan dengan apa yang Caruth (1995) ungkapkan bahwa pemerkosaan maupun kekerasan pada anak-anak adalah beberapa dari sekian banyak penyebab gangguan stress pasca trauma (Post-traumatic Stress Disorder). Mengenai kekerasan seksual terhadap anak-anak, Cristiane Olivier berpendapat Ces enfants-là non seulement s'arrêtent de vivre à la façon des enfants, mais ne pourront jamais vivre comme des adultes Anak-anak itu (yang mengalami pelecehan) tidak hanya berhenti hidup sebagai anak-anak, tetapi juga tidak pernah dapat hidup sebagai orang dewasa (1998: 137). Seorang anak yang mengalami pelecehan, berada dalam dunia yang membingungkan. Hal ini dikarenakan peristiwa seksual yang dialami anak tersebut merupakan sesuatu yang pada umumnya hanya dimengerti oleh orang dewasa. Anak-anak belum mempunyai informasi yang cukup untuk mengerti apa yang terjadi. Oleh karena itu, tokoh Lucie tidak bisa menyampaikan apa yang terjadi pada dirinya pada siapapun, termasuk pada orang tuanya. Gambaran akan apa yang me-nimpa Lucie disampaikan narator dengan bahasa dongeng, mitos, dan cerita khas anak-anak. Hal ini sejalan dengan Arva yang menyatakan bahwa realisme magis memberikan peluang pada pengarang untuk mewakili apa yang tidak bisa direpresentasikan. Mengacu pada 'muteness of trauma' dan ekstremitas yang tak terkatakan, Arva berpendapat bahwa 'realisme magis memiliki ke- mampuan unik untuk mengubah apa yang tidak bisa digambarkan, menjadi realitas yang dapat diakses' (2008: 74)

Alusi terhadap dongeng dinarasikan saat Anne-Lise Limbourg dan Irène Vassal, teman Lucie, ditemukan meninggal dunia dan terdapat indikasi pemerkosaan pada keduanya. Saat Lucie meminta penjelasan kepada ibunya, si ibu menghindari topik tersebut. Kata-kata seperti kejahatan (crime) dan pemerkosaan (viol) menjadi sesuatu yang tidak pernah diucapkan, maka Lucie menyimpulkam bahwa kata-kata yang tidak terucap itu adalah des noms terribles, comme sont dans les contes les noms "ogre", loup, maraître ou sorcière (kata-kata yang buruk, seperti dalam dongeng-dongeng ada nama-nama Oger, Serigala, ibu tiri jahat, atau penyihir) (Germain, 1991 : 66). Lalu Lucie mengasosiasikan semua kejadian itu dengan dongeng yang ia ketahui. Ia menyebut pelaku kejahatan sebagai Oger.

Un ogre a tué Anne-Lise. Mais la petite fille n'est pas morte; enfin, pas comme les hérissons, les chats, les musaraignes ou les oiseaux que l'on trouve parfois écrasés sur les bords des routes ou crevés dans les champs. Anne-Lise est partie "chez dieu", elle est devenue semblable aux chérubins (Germain, 1991: 67)

Oger telah membunuh Anne-Lise. Tetapi gadis kecil itu tidak mati; pada akhirnya, tidak seperti landak, kucing, tikus atau burung yang terkadang ditemukan hancur di sisi jalan atau tertusuk di ladang. AnneLise pergi "ke rumah Tuhan", ia menjadi seperti malaikat kecil (Germain, 1991: 67). 
Dari kutipan tersebut, terdapat pemikiran khas anak-anak yang dekat dengan dongeng maupun kisah keagamaan. Hal ini menyiratkan adanya usaha dari seorang anak untuk dapat mencerna kenyataan yang mengerikan. Konsep sederhana dongeng mengenai tokoh baik/jahat, pahlawan/penjahat, memberikan referensi bagi anak-anak dalam mengekspresikan pemikiran atau perasaan mereka terhadap dunia dan membantu mereka memahami dunia orang dewasa. Akhir dongeng yang menjanjikan happily ever after juga memberikan harapan bagi anak-anak bahwa penderitaan akan segera berlalu dan mereka akan melewati semua kejadian buruk.

Selanjutnya Lucie juga mengalami hal yang sama, yaitu diperkosa oleh kakak tirinya yang datang setiap malam melalui jendela kamarnya. Dalam narasi, bahasa yang Lucie gunakan adalah bahasa dongeng, Hanya dengan kata-kata tersebut ia dapat menggambarkan apa yang terjadi pada dirinya. Lucie bahkan tidak dapat menemukan kata-kata yang tepat untuk memberitahu dan meminta tolong pada ibunya mengenai kekejian sang kakak.

il a bu, il va se coller contre elle, il va se frotter à elle, et lui écarteler les membres comme on le fait avec des insectes ou des grenouilles de dissection. Il a bu, il va sombrer dans un sommeil lourd sitôt sa faim assouvie (Germain, 1991:115)

Setelah dia (Ferdinand) minum, dia akan menempel padanya (Lucie), ia akan menggosokkan diri padanya, dan membuka anggota badannya seperti yang dilakukan terhadap serangga atau kodok saat pembedahan. Setelah ia minum, ia akan tenggelam dalam tidurnya ketika rasa laparnya terpuaskan (Germain, 1991:115)

Paragraf tersebut tidak secara eksplisit menggunakan kata la viole yang berarti pemerkosaan, tetapi dengan jelas dapat diketahui bahwa sa faim, yang berarti rasa lapar mengacu pada hasrat seksual Ferdinand kepada Lucie. Germain menempatkan begitu banyak bukti sehingga pernyataan bahwa Lucie telah diperkosa menjadi tak terbantahkan lagi, meski kata-kata eksplisit mengenai seks, organ-organ genital ataupun penetrasi tidak terlihat.

Lucie setiap malam selalu terjaga karena takut Ferdinand datang. Dengan mengaitkan Ferdinand pada sosok Oger, diketahui bahwa narator mengambil sudut pandang dari sisi Lucie sebagai anak yang mencoba memahami peristiwa ekstrem, dalam hal ini pemerkosaan, yang dialaminya. Ferdinand diibaratkan sebagai Oger karena dalam dongeng, Oger digambarkan selalu berhasrat pada daging anak-anak. Tetapi, Oger yang mengacu pada tokoh Ferdinand, bukanlah sosok Oger yang buruk rupa, melainkan Oger yang sangat tampan (1991: 53). Penggambaran tokoh Ferdinand yang tampan tetapi jahat, menunjukkan bahwa gambaran fisik tokoh tidak berbanding lurus dengan sikapnya seperti biasa yang terdapat dalam dongeng. Dengan demikian, meski mengacu pada dongeng, Germain melakukan perubahan dalam hal karakter baik/jahat yang tidak bergantung pada penampilan fisik. Dalam dunia Germain, si penjahat berwajah tampan dan si korban berpenampilan sangat buruk. 
Pemerkosaan sebagai kejahatan yang digambarkan pada novel ini, bukanlah kejahatan biasa, tetapi merupakan gambaran dari kuasa dan dominasi dari laki-laki terhadap perempuan, dominasi orang dewasa terhadap anakanak yang tidak berdaya "Elle attend comme attendent les proies qui ne peuvent s'enfuir (ia -Lucie- menunggu seperti menunggunya mangsa yang tidak bisa melarikan diri» (1991: 99). Seperti yang diungkapkan oleh Olivier(1998), anakanak tidak memiliki kekuatan untuk membela diri dari pemerkosaan yang pada umumnya hanya dimengerti oleh orang dewasa. Anak-anak belum mempunyai informasi yang cukup untuk mengerti apa yang terjadi.

Trauma pada tokoh Lucie telah mengubahnya dari anak perempuan yang ceria menjadi anak yang muram. Ia juga tidakpernah tersenyum, tertawa, atau menangis lagi. Lucie mengungkapkan bahwa sang Oger telah mencuri semua hal darinya, termasuk air matanya. Ketidakampuan menangis setelah mengalami kekerasan tersebut menandakan bahwa Lucie berada dalam keheningan total. Ia pun memutuskan untuk menjauh dari keluarga, teman-teman, dan lingkungan sekitarnya. Kebungkaman, keheningan, atau silence pada perempuan dianggap sebagai tanda ketidakberdayaan pihak yang ditekan. Tetapi, Jaworski sebagaimana dikutip oleh Carrette menganggap bahwa silent dan being silenced adalah dua hal yang berbeda. Menurutnya, silence di pihak perempuan telah berubah dan berevolusi, lebih lanjut ia mengungkapkan:

Historically women were/are silenced as a 'muted' and 'nameless' group; women then broke off the silence by reclaiming their experience; but significantly silence was still strategically used as a powerforce against male language. (Carrette: 33)

Dari teks tersebut, Jaworsky mengargumentasikan bahwa perempuan telah keluar dari fase silence ketika perempuan mengatakan pengalaman mereka. Namun, hal ini tidak serta merta menghilangkan silence sebagai sebuah strategi perlawanan tersendiri. Cara ini adalah perlawanan terhadap dominasi bahasa laki-laki.Fase silence Lucie ini ialah usaha Germain dalam memberikan kekuatan dan otoritas terhadap Lucie. Fase silence tokoh Lucie merupakan sebuah strategi dan pilihan. Lucie harus tetap diam agar pengasingan dirinya bersifat absolut. Dengan begitu ia dapat mengikis semua hal yang mengajaknya berbicara. Awalnya memang karena tekanan, tetapi ketika Lucie digambarkan merasa nyaman dengan kondisi tersebut berarti ia 'memilih' untuk tetap dalam ruang silence karena ia merasa mendapatkan kebebasan.

Tokoh Lucie yang juga menemukan penghiburan dari alam, mendapatkan ide untuk membalas dendam dengan mempelajari lingkungan sekitarnya. Ia menatap serangga dalam genangan air selama berjam-jam, dan terinspirasi oleh kekejaman mereka yang tenang «cruauté sereine». Maka suatu malam, saat si Oger tengah berbaring di kebun dan terlalu mabuk untuk naik ke jendela, Lucie berdandan sejelek mungkin dan duduk di pagar. Dia mengaitkan foto dua korban yang telah dibunuh si Oger; dan Ferdinand dipaksa untuk melihat apa yang sudah dilakukannya, untuk mengingat dosanya. Karena tatapan Lucie dan foto kedua korban si 
Oger terdiam seolah menjadi patung. Setelah itu, Lucie mengunjungi si Oger di kamarnya setiap hari untuk memastikan dia tidak terbangun. Dunia mistis ini telah menjadi jalan seorang anak untuk bertahan hidup.

Narator tidak menceritakan dengan detail luka apa yang dialami Ferdinand, tetapi peristiwa itu mengharuskan Ferdinand dirawat di rumah sakit akibat kelumpuhan total dan dilanjutkan dengan perawatan di rumah karena tidak ada kemajuan yang berarti. Sebagaimana diargumentasikan oleh Langdon, sifat teks realisme magis yang ambigu sering menyebabkan pembaca untuk kehilangan alur, hal ini bertujuan untuk membuat pembaca merasakan pengalaman, daripada secara obyektif memahami peristiwa yang terjadi (2011: 22).

Lucie yang merasakan kebencian besar terhadap kakaknya merasa bahwa ia mempunyai kesempatan utuk membalas dendam. Maka setiap hari, jika kakaknya sedang tidak dijaga ibunya, ia masuk ke kamar kakaknya dengan diam-diam. Berikut penggambaran aksi balas dendam Lucie: Ia mengeluarkan senter bercahaya dari sakunya dan menyalakan cahaya itu terkadang ke arah mata yang terbaring, terkadang ke arah wajahnya sendiri. Dari sakunya ia juga mengeluarkan kotak korek api di mana ia menyimpan belalang. Ia menekankan kotak bersuara itu ke telinga yang terbaring. Ia juga memegangnya cukup lama (Germain, 1991: 200).

Kutipan tersebut memaparkan tindakan Lucie saat melakukan aksi balas dendamnya. Alat-alat yang digunakan Lucie bukanlah alat-alat tajam mengerikan, tetapi ia menggunakan peralatan bermainnya. Aksi balas dendam gaya anak-anak ini memperlihatkan keluguan tokoh Lucie sebagai anak kecil. Lucie juga menggunakan binatang peliharaannya, yaitu berbagai jenis serangga dan reptil, untuk 'menyiksa' kakaknya, elle dépose sur son visage des bestioles gluantes (ia (Lucie) meletakkan binatang-binatang berlendir di wajahnya (Ferdinand) (Germain, 1991: 212). Lucie menganggap bahwa serangga juga memiliki kekuatan pertahanan diri dan menyerang. Dengan demikian, ia membalaskan dendamnya dengan tidak menggunakan kekerasan seperti yang dilakukan oleh kakaknya. Germain bahkan meyakinkan bahwa ini bukanlah masalah realitas ataupun hayalan lagi. Il n'y a désormais plus la moindre frontière entre la réalité et l'imaginaire (Tidak ada lagi batas antara realitas dan khayalan) (Germain, 1991: 79).

Hal lain yang menarik adalah, naratorjuga mengungkapkan sudut pandang Ferdinand di akhir masa hidupnya. Narator menggambarkan kengerian si pelaku memandangi foto-foto korbannya. Bagi Ferdinand sendiri, kejahatan yang dilakukannya tetap menjadi sesuatu yang terus menghantuinya. Dalam keadaan lumpuh, ia membayangkan dua korban yang telah diperkosanya (Germain, 1991: 193) Jiwa Ferdinand yang diteror oleh ingatan-ingatan mengenai kejahatan yang ia lakukan. Tidak berapa lama setelah 'kunjungan' Lucie tersebut, Ferdinand meninggal. Dengan demikian, tokoh Lucie digambarkan telah sukses membalaskan dendamnya meskipun dengan cara lugu khas anak-anak.

Kekuatan dan kejahatan sang Oger sebagai tokoh jahat mengubah Lucie menjadi monster yang lebih buruk dan lebih jahat: Medusa. Oger dapat menyakiti secara fisik dan Medusa, mela- 
lui matanya bisa mengubah seseorang menjadi batu. Mitos Medusa digunakan untuk mendeskripsikan Lucie sebagai anak yang begitu menderita sehingga ia mengubah dirinya sendiri menjadi sosok Gorgon, mahluk buruk rupa yang dapat mengubah orang menjadi batu hanya dengan pandangan matanya. Saat Ferdinand jatuh dalam keadaan mabuk yang membuatnya pingsan, Lucie memanfaatkan kesempatan tersebut untuk memandanginya C'est un regard qui siffle, et grince, et saigne, [...] Un regard de Méduse (itu adalah pandangan yang menghembus, berderit, dan berdarah, [...] padangan Médusa) (Germain, 1991:145).

Pandangan Medusa dari Lucie ini digambarkan telah melumpuhkan Ferdinand dan kemudian membunuhnya. Melalui peristiwa tersebut pembaca akan bertanya-tanya benarkah Ferdinand mati karena dibunuh dengan caracara konyol yang Lucie lakukan atau karena alasan lain. Berkenaan dengan hal ini Arva berargumentasi bahwa realisme magis menolak ide a single or fixed version of truth or reality, pada saat yang bersamaan realisme magis akan terus menerus memperlihatkan kegagalannya untuk mencapai representasi dunia yang akurat (2008: 78).

Seolah ingin menjelaskan bahwa segala sesuatu ada sebab dan akibat, di akhir cerita narator menjelaskan bahwa tokoh Lucie adalah korban dari favoritisme keluarga. Ibu Lucie lebih menyayangi Ferdinand dan cenderung mengabaikan Lucie. Favoritisme ini tidak mendatangkan kebaikan bagi keduanya. Tokoh ibu, Aloïse, tidak bisa memandang Ferdinand sebagai anak tanpa mengaitkannya pada sosok Victor, suaminya yang telah meninggal.
Aloïse yang tidak pernah bisa melupakan kenangan tentang suaminya, seolah menemukan lagi sosok suaminya melalui Ferdinand. Dari sudut pandang Aloïse ini sosok Ferdinand digambarkan sangat mirip dengan ayahnya. Dapat dikatakan bahwa penderitaan Aloïse yang kehilangan suaminya juga telah menyebabkan Ferdinand menjadi korban. Tokoh Ferdinand tidak mampu membangun sebuah identitas yang stabil karena ibunya bersikeras bahwa dia adalah perwujudan dari ayahnya yang telah meninggal (Germain, 1991: 174).

Dari cerita tersebut terungkap bahwa tokoh Ferdinand menempati dua peran sekaligus dalam cerita novel ini, yaitu sebagai pelaku kejahatan dan korban kejahatan. Kejahatan yang menimpa Ferdinand secara tidak langsung diakibatkan oleh kejahatan yang lebih besar, yaitu perang. Ibu Ferdinand, Aloïse, kehilangan ayah dan suaminya, Victor, karena tewas di medan perang. Aloïse yang tidak ingin kehilangan lagi orang yang dicintainya, memfokuskan seluruh perhatian dan cintanya pada Ferdinand yang ia anggap sebagai pengganti suaminya. Jadi, Ferdinand adalah tokoh yang menjadi hasrat rahasia ibunya, Aloïse. Perlakuan yang tidak wajar dari ibu kepada anak ini telah menyebabkan trauma tersendiri bagi tokoh Ferdinand (Germain, 1991:86).

Kematian Victor Morrogues, ayah Ferdinand, tidak hanya membuat Aloïse menderita, tetapi juga membuat Ferdinand kehilangan masa anak-anak yang bahagia. Ferdinand tidak mengalami masa kecil seperti anak-anak pada umumnya. Ferdinand juga menjadi laki-laki yang tidak mampu mencintai dan bertanggung jawab, ia menjadi Oger yang dikuasai oleh hasrat terhadap 
anak kecil. Maka keterangan mengenai Ferdinand n'était pas méchant (Ferdinand tidak jahat) (Germain, 1991:196) menyiratkan bahwa Ferdinand juga adalah korban dari bentuk trauma lain, yaitu perang.

Berdasarkan penelusuran tokoh Lucie dapat diketahui bahwa alusi pada mitologi Yunani seperti kisah CastorPollux, Orphée-Eurydice, Medusa, dan pada dongeng, yaitu Oger, muncul sebagai cara untuk memahami berbagai kejadian ekstrem yang dialaminya sekaligus menjadi kekuatan bagi tokoh Lucie untuk melawan penindasan. Narasi realisme magis yang Germain gunakan merupakan keberpihakan narator pada tokoh utama sebagai korban dan sebagai suara yang mampu memaparkan peristiwa mengerikan yang tak bisa diungkapkan.

\section{SIMPULAN}

Pada novel JC dan EM, alur cerita yang tidak kronologis menciptakan semacam teka-teki bagi pembaca yang hanya dapat dipecahkan dengan menelusuri pemaparan narator. Peristiwaperistiwa utama dalam kedua novel, khususnya yang berkaitan dengan kejahatan seperti pembunuhan dan pemerkosaan tetap menjadi rahasia para tokoh yang mengalaminya. Dengan menampilkan flashbackyang berulang sejalan dengan pemikiran tokoh untuk mengenang dan memaparkan peristiwa tertentu, serta penggunaan berbagai metafora dalam cerita merupakan strategi yang efektif untuk menarasikan trauma yang dialami para tokoh.

Trauma tersebut disebabkan oleh hal yang berbeda. Pada novel JC, trauma tokoh Ambroise, Reine dan Simon diakibatkan oleh rasa kehilangan orang yang dicintai, sama seperti trauma tokoh Aloïse dan Ferdinand pada novel EM. Sementara itu, tokoh Lucie mengalami trauma akibat pemerkosaan yang dilakukan kakaknya.

Hal-hal magis telah membawa kekuatan tersendiri pada tokoh-tokoh tersebut yang juga memiliki makna tersendiri. Pada JC realisme magis yang melingkupi tokoh Ambroise Mauperthuis berfungsi sebagai cara mengungkap kejadian ekstrem yakni pembunuhan sekaligus rasa trauma akan kehilangan orang yang dicintai, pada tokoh Reinette dapat bermakna kekuatan dan pada tokoh Simon bermakna penggambaran duka yang mendalam. Sementara itu pada EM, realisme magis merupakan strategi untuk mengungkapkan trauma tokoh Lucie sebagai korban kekerasan seksual. Melalui cerita dalam kedua novel ini, realisme magis membuktikan kemampuannya untuk merepresentasikan trauma, horror, serta kejadian yang sulit atau tidak mungkin diungkapkan secara akurat melalui penggunaan narasi realis tradisional.

\section{UCAPAN TERIMA KASIH}

Kami ucapkan terima kasih yang sebesar-besarnya pada Direktorat Riset, Pengabdian kepada Masyarakat dan Inovasi (DRPMI) Universitas Padjadjaran yang telah mendanai penelitian ini dalam program Hibah Internal Unpad (HIU) tahun 2018. Selain itu, penelitian ini tidak mungkin terlaksana tanpa kontribusi berharga dari Icha Ayu Huré, Witakania Som, serta Sarah Anaïs Andrieu yang memungkinkan kami mendapatkan buku-buku referensi langsung dari Perancis. 


\section{DAFTAR PUSTAKA}

Arva, E. L. 2008. Writing the Vanishing Real: Hyperreality and Magical Realism. Journal of Narrative Theory, vol. 38, no. 1, Winter, pp. 60-85. https://hispanlit.qwriting.qc.cuny. edu/files/2011/06/Writing-theVanishing-Real1.pdf

Arva, E. L. 2008. Writing trauma: The Holocaust in magical realist fiction. Beyond Philology:An International Journal Of Linguistics, Literary Studies And English Language Teaching. (5)75-104. https://www.academia. edu/31059013/Writing_Trauma_ The_Holocaust_in_Magical_Realist_Fiction

Balaev, M. (2008). Trends in Literary Trauma Theory. Mosaic: An Interdisciplinary Critical Journal,41(2), 149-166. http://www.jstor.org/ stable/44029500

Carrette, J. R. 2000. Foucault and Religion Spiritual corporality and political spirituality. New York: Routledge.

Caruth, C.. 1995. Trauma and Experience: Introduction. Trauma: Exploration in Memory. Baltimore and London: The Johns Hopkins University Press.

Chanady, A.. 1985.Magic Realism and the Fantastic. Resolved versus Unresolved Antinomy. New York: Garland Publishing.

Deleuze, G.. Guattari, Felix. 1980. Capitalisme Et Schizophrénie: Mille Plateaux. Paris: Les Éditions De Minuit.

Faris, B. W., 2004. Ordinary Enchantements Magical Realism and the Remystification of Narrative. Nashville: Vanderbilt University Press.

Faris, W. B., Parkinson Zamora. 1995. Magical realism: Theory, History, Com- munity. London: Duke University Press.

Genette, G.. 1972. Figures III. Paris: Edition du Seuil.

Germain, S.. 1989. Jours de Colère. Paris: Gallimard

Germain, S.. 1991. L'Enfant Méduse. Paris: Gallimard.

Goulet, A. 2006. Sylvie Germain: Ouvre Romanesque. Paris: L'Harmattan.

Harvey, J. H. 2002. Perspectives on Loss and Trauma: Assault On The Self. London: Sage Publication.

Horáčková, C. F.. 2014. Traumatic Histories: Representations of (Post-) Communist Czechoslovakia In Sylvie Germain, Daniela Hodrová, And JeanGaspard Pálenícek. Department of Modern Languages at the University of Exeter. South West England, United Kingdom. https://core. ac.uk/download/pdf/43095210. pdf

Jauer, A.. 2016. Hybridité et altérité dans Magnus de Sylvie Germain. Quêtes littéraires $n^{\circ} 6,2016$.AixMarseilleUniversité. http://www. kul.pl/files/60/quetes_litteraires_ n6_2016_annick_jauer.pdf

Kristeva, J.. 1982. Powers of Horror - An Essay on Abjection, New York: Columbia University Press.

Langdon, J. 2011. Magical Realism and Experiences of Extremity. Current Narratives. Vol 1, issue 3. 14-24. http:// ro.uow.edu.au/currentnarratives/ vol1/iss $3 / 4$

Lutas, L.. 2017. Réalisme magique ou fantastique? - Stratégies narratives dans la réappropriation des traumatismes historiques. 60-82. Vol. 111. No. 1. 2017Moderna spark - Institutionen för moderna spark. http://ojs.ub.gu. 
se/ojs/index.php/modernasprak/article/view/3509

M. Hart, S., Wen-chin Ouyang. 2005. A Companion To Magical Rea-lism. Tamesis. Woodbridge.

Olivier, C.. 1998. L'Ogre Intérieur: de la Violence Personelle et Familiale. Paris: Librairie Arthème Fayard.

Ratna, KR.. 2011. Teori, Metode, dan Teknik Penelitian Sastra. Yogyakarta: Pustaka Pelajar.

Roussos, K.. 2007. Décoloniser l'imaginaire: du réalisme magique chez Maryse Condé, Sylvie Germain et Marie Ndiaye. Paris: L'Harmattan.

Schönfelder, C.. 2013. Wounds and Words: Childhood and Family Trauma in Romantic and Postmodern Fiction. Bielefeld: Transcript Verlag.

Sherratt-B., Dawn Miranda. Things We'd Rather Forget': Trauma, the Troubles, and Magical Realism in Post-Agreement Northern Irish Women's Short Stories. (2018) 4(2): 12 Open Library of Humanities, DOI: https://doi. org/10.16995/olh.247

Todorov, T.. 1970. Introduction à la littérature fantastique. Paris: Éditions du Seuil.

Warnes, C. 2009. Magical Realism and the Postcolonial Novel Between Faith and Irreverence. New York: Palgrave Macmillan. 